\title{
Bioassay Method for Toxicity Studies of Toxic Bait Formulations to Ceratitis capitata (Diptera: Tephritidae)
}

\author{
CA Baronio ${ }^{1}$, D Bernardi ${ }^{1,2}$, MZ Nunes $^{1}$, J Pasinato ${ }^{3}$, FRM Garcia ${ }^{1}$, M Botton $^{3}$ \\ 'Depto de Fitossanidade, Faculdade de Agronomia, Univ Federal de Pelotas, Pelotas, Rio Grande do Sul, Brasil \\ ${ }^{2}$ Dept of Entomology, Embrapa Clima Temperado, Pelotas, RS, Brasil \\ ${ }^{3}$ Embrapa Uva e Vinho, Bento Gonçalves, Rio Grande do Sul, Brasil
}

\section{Keywords}

Toxicity, methodology, spinosad, Mediterranean fruit fly

\section{Correspondence}

D Bernardi, Dept of Entomology, Embrapa

Clima Temperado, Pelotas, RS, Brasil;

dbernardi2004@yahoo.com.br

Edited by Rafael M Pitta - Embrapa

Received 20 August 2018 and accepted 9 November 2018

(C) Sociedade Entomológica do Brasil 2018

\begin{abstract}
The development of appropriate methodologies for bioassays is of paramount importance to study the methodological factors that may interfere in the experimental design. Thus, laboratory bioassays have become increasingly important for the determination of data that are realistic and replicable. The objective of the study was to develop a bioassay methodology with the ready-to-use toxic bait Success ${ }^{\mathrm{TM}} 0.02 \mathrm{CB}, 96 \mathrm{mg} \mathrm{L}^{-1}$ of spinosad, in adults of Ceratitis capitata (Wiedemann) as a study model. The insect origin (laboratory population, $\mathrm{LT}_{50}=11.16 \mathrm{~h}$ ), time of toxic bait supply ( $\left.4 \mathrm{~h}, L_{50}=16.85 \mathrm{~h}\right)$, food deprivation $\left(12 \mathrm{~h}, \mathrm{LT}_{50}=15.55 \mathrm{~h}\right)$, and the adult age ( 5 days, $\mathrm{LT}_{50}=35.31 \mathrm{~h}$ ) of $\mathrm{C}$. capitata showed higher susceptibility and a shorter $\mathrm{LT}_{50}$ lethal time to the Success ${ }^{\mathrm{TM}} \mathrm{O} 0 . \mathrm{O} \mathrm{CB}$ toxic bait. However, the absence or presence of a food source $\left(\mathrm{LT}_{50} \approx 31.17 \mathrm{~h}\right)$ during the bioassay did not affect the susceptibility of $C$. capitata. Further, adults of $C$. capitata who were deprived and in the absence of a food source (artificial diet) had higher consumption of toxic baits $(\mathrm{mg})$ during treatment exposure. The use of a 12-h deprivation period, toxic baits offered for $4 \mathrm{~h}$, and absence of an artificial diet for adults of $C$. capitata at 5 days of age during the bioassay are considered adequate for evaluating formulations of toxic baits under laboratory conditions.
\end{abstract}

\section{Introduction}

Mediterranean fruit fly Ceratitis capitata (Wiedemann) (Diptera: Tephritidae) is a polyphagous and cosmopolitan specie with a high capacity for infesting and damaging 361 host species belonging to 63 botanical families worldwide (McQuate \& Liquido 2017). In Brazil, there are records of the occurrence of the pest in 93 host species belonging to 27 botanical families (Adaime et al 2017). Due to the high number of hosts and large dispersal capacity of $C$. capitata, especially in areas of commercial fruit production, the main management strategy is through chemical control with the use of insecticides in cover sprays and toxic baits (Morelli et al 2012, Botton et al 2016).
The application of toxic baits in aerial or terrestrial spray is a good alternative to fruit fly management (Raga \& Sato 2005, Navarro-Llopis et al 2012, Raga \& Galdino 2018). Because they are formulated from a food lure composed of proteins and carbohydrates associated with a lethal agent (Medina et al 2007), toxic baits act by attracting and intoxicating adults of the Mediterranean fruit fly who are searching for food sources for maintenance of energy reserves and maturation of the reproductive apparatus (Silva-Neto et al 2010, Raga \& Sato 2016). In Brazil, sugarcane molasses (a byproduct of the sugar-making process containing reducing sugars and uncrystallized sucrose) and hydrolyzed proteins of plant origin (maize) are the main attractions used in the formulation of toxic baits for the management of C. capitata and Anastrepha fraterculus (Wiedemann) (Diptera: 
Tephritidae) (Raga \& Sato 2005, Morelli et al 2012, Araújo et al 2013, Borges et al 2015, Härter et al. 2015). However, in addition to the toxic baits formulated in rural properties (Botton et al 2016), a ready-to-use toxic bait formulation (Success ${ }^{\mathrm{TM}} \mathrm{O}$.02CB) has recently been introduced in the Brazilian market that has spinosad as a lethal agent. This agent, known internationally as GF-120 ${ }^{\mathrm{TM}}$ NF (Prokopy et al 2004), is authorized for use in several crops in Brazil for the control of A. fraterculus, Anastrepha obliqua (Mcquart) (Diptera: Tephritidae), Bactrocera carambolae Drew and Hancock (Diptera: Tephritidae), and C. capitata (Agrofit 2018).

To develop, improve, and make available new formulations of toxic baits for the handling of fruit flies in the field, laboratory studies are important for the characterization of possible factors that may interfere in the toxicological characterization of the products, such as the type of attractant feeding time, exposure time, insect origin (field population or laboratory population without insecticide selection pressure), insect age, feed deprivation period, and mode of availability of the formulations (Stark et al. 2004, Medina et al 2007, Raga and Sato 2011, Gazit et al 2013). Analysis of these factors is fundamental for determining and establishing adequate bioassay methodologies in order to avoid misguided and erroneous conclusions about a certain toxic bait formulation and to affect management recommendations (Zwolfer 1983).

In testing and toxicological characterization of formulations of toxic baits on fruit fly species, there is no methodological standardization for evaluations and this may negatively affect results and compromise the reliability of the data (Humeres et al 1999, Robertson et al 2007, Gazit et al 2013, Paramasivam \& Selvi 2017). To address these limitations, in this study, was to develop a bioassay methodology, considering factors such as age and origin of the population, time of food deprivation, and form and time of availability of the product to assess the effects on adults of $C$. capitata using as toxicological standard the Success ${ }^{\mathrm{TM}} 0.02 \mathrm{CB}$ commercial formulation ( $96 \mathrm{mg} \mathrm{L}^{-1}$ active ingredient spinosad).

\section{Material and Methods}

Insects

Adults of $C$. capitata were obtained from the Entomology Laboratory of Embrapa Grape and Wine, Bento Gonçalves, Rio Grande do Sul, Brazil, and were kept in air-conditioned rooms (temperature of $25 \pm 2{ }^{\circ} \mathrm{C}$, relative air humidity of $70 \pm$ $10 \%$, and photoperiod of $12 \mathrm{~h}$ ), rearing $C$. capitata adults with an artificial diet composed of a mixture of wheat germ, beer yeast, and brown sugar (3:1:1) offered in Petri dishes, and larvae fed with an artificial diet according to Nunes et al (2013).

\section{Bioassays}

All bioassays were performed in a climate room (temperature of $25 \pm 2^{\circ} \mathrm{C}$, relative air humidity of $70 \pm 10 \%$, and photoperiod of $12 \mathrm{~h}$ ). The insects used in the different bioassays came from a susceptible population of $C$. capitata, which is kept in laboratory for 5 years, free of selection pressure by insecticides. For the bioassays, adults of $C$. capitata were packed inside plastic containers (300 $\mathrm{mL}$ ) as proposed by Medina et al (2007) and Gazit et al (2013). The toxic bait used in the bioassays was the Success ${ }^{\mathrm{TM}}$ 0.02CB formulation (Dow Agrosciences, Santo Amaro, Sao Paulo, Brazil), diluted in proportion as one-part commercial product to 1.5 parts water, resulting in a concentration of $96 \mathrm{mg} \mathrm{L}^{-1}$ of spinosad (Barry et al 2006, Agrofit 2018). The bioassay method was based on the ingestion of a drop of $40 \mu \mathrm{L}$ deposited on a $1-\mathrm{cm}^{2}$ polyethylene terephthalate (PET) plastic plate with the aid of graduated single-channel micropipette Gilson ${ }^{\mathrm{TM}}$ model Pipetman U76928A with 1-mL capacity and left for $2 \mathrm{~h}$ at room temperature $\left(25^{\circ} \mathrm{C}\right)$ to allow drying and evaporation of water. For all bioassays, the toxic bait was provided for $4 \mathrm{~h}$. The insects were fed an artificial diet composed of a mixture of wheat germ, beer yeast, and brown sugar (3:1:1) supplied inside acrylic lids (2-cm diameter) and distilled water in plastic caps (2-cm diameter) lined with hydrophilic cotton. Similarly, in all bioassays, adult mortality of $C$. capitata in treatments and for estimates of lethal times $\left(\mathrm{LT}_{50}\right)$ was evaluated at 1, 3, 6, 12, 24, 48, 72, and $96 \mathrm{~h}$ after exposure (HAE) of the toxic bait. Insects were considered dead when they did not exhibit reaction to the touch of a fine brush. Adult mortality of $C$. capitata was corrected by the formula of Henderson \& Tilton (1955).

\section{Susceptibility of C. capitata populations as a function of origin}

Two populations of $C$. capitata were used: a population from the field (first generation) from insects collected from mango fruits (Mangifera indica L.) collected in the municipality of Casa Nova, Bahia, Brazil ( $9^{\circ} 1850679 S ; 40^{\circ} 5250000 W$ ), infested with $C$. capitata larvae, and a population established and maintained in the laboratory on an artificial diet as previously described. Adults that emerged from the two larval feeding substrates (mango fruits or artificial diet) were grown in semitransparent plastic cages $(41.0 \times 29.5 \times$ $30.0 \mathrm{~cm}$ in length, width, and height, respectively) containing distilled water supplied via capillarity by means of a strip of vegetable sponge (Spontex ${ }^{\mathrm{TM}}$ ) and were fed an artificial diet composed of soybean extract, wheat germ, and brown sugar at the ratio of 3:1:1. The experimental design was completely randomized with 10 replicates (five couples per replicate) per treatment. Subsequently, adults of both populations (treatments) within 5 to 8 days old were packaged in plastic 
containers $\left(300 \mathrm{~mL}\right.$ ) and fed with a toxic bait (Success $\mathrm{s}^{\mathrm{TM}}$ $0.02 \mathrm{CB}$, one drop of $40 \mu \mathrm{L}$ ) for a period of $4 \mathrm{~h}$. After this time, the insects were fed with an artificial diet. As a negative control, adults of $C$. capitata were fed only the artificial diet. The experimental design was completely randomized with 10 replicates (five couples) per treatment.

\section{Availability of toxic bait to C. capitata together with the supply of artificial food}

Adults of $C$. capitata ( 5 days old) obtained from the group maintained on the artificial diet were placed inside plastic containers $(300 \mathrm{~mL})$, as described in the previous bioassay. To verify the effects of the presence or absence of the artificial diet on adults of $C$. capitata during the period of exposure to the feeding of the toxic bait formulation, the treatments ( $T$ ) were the following: ( $\mathrm{T} 1$ ) adults of $C$. capitata exposed to the toxic bait Success ${ }^{\mathrm{TM}} 0.02 \mathrm{CB}$ (one drop of $40 \mu \mathrm{L}$ ) + distilled water provided as previously described, with the provision of artificial diet; (T2), adults of $C$. capitata were exposed only to toxic bait (Success ${ }^{\mathrm{TM}}$ 0.02CB, one drop of $40 \mu \mathrm{L}$ ) + distilled water as feed substrates, according to the methodology described above; and (T3), adults of C. capitata received only artificial diet + water, without the presence of toxic bait. The experimental design was completely randomized with 10 replicates (five couples per replicate).

\section{Exposure time of toxic bait to adults of $\boldsymbol{C}$. capitata}

To evaluate the exposure time of the toxic bait, adults of C. capitata (5 to 6 days old) obtained from the group maintained in the artificial diet were packed inside plastic containers (300 $\mathrm{mL}$ ), as previously described. Subsequently, the insects were exposed to feed for $1,2,4$, and $8 \mathrm{~h}$ on the toxic bait Success ${ }^{\mathrm{TM}} \mathrm{0.02CB}$ (one drop of $40 \mu \mathrm{L}$ ) without the presence of artificial diet. After the withdrawal of the toxic bait during the determined exposure periods, artificial diet was offered to the adults until the end of evaluation. The experimental design was completely randomized with 10 replicates (five couples per replicate).

Toxicity of toxic bait on adults of $\boldsymbol{C}$. capitata as a function of the age of the insects

In this bioassay, adults of $C$. capitata from the rearing of maintenance with ages (treatments) of 1,5 , and 8 days old (after the emergence) were used. These are the ages at which females present a lower percentage of mature ovaries, developing ovaries, and high mature ovaries (Arita 1982). The insects were packed into plastic containers $(300 \mathrm{~mL})$ and then the toxic bait (Success ${ }^{\mathrm{TM}} \mathrm{O} .02 \mathrm{CB}$, one drop of $40 \mu \mathrm{L}$ ) was provided for a 4 -h period as described above. After this period, the toxic baits were removed, and the insects were fed with artificial diet and water. The experimental design was completely randomized with 10 replicates (five couples per replicate).

\section{Period of food deprivation prior to toxic bait exposure}

Adults of $C$. capitata ( 5 days old) from the group maintained on the artificial diet were submitted to periods (treatments) of $\mathrm{O}, 12$, and $24 \mathrm{~h}$ of food deprivation (artificial diet). After the deprivation periods of each treatment, the insects were transferred to cages made of plastic containers (300 $\mathrm{mL}$ ), as described previously, where they were exposed to a drop of $40 \mu \mathrm{L}$ of the Success ${ }^{\mathrm{TM}} 0.02 \mathrm{CB}$ toxic bait. As a negative control (control treatment), the insects received only artificial diet and water. The experimental design was completely randomized with 10 replicates (five couples per replicate).

\section{Data analysis}

The data on mortality and consumption of toxic bait were submitted to studentized residual analysis to confirm the assumption of normality using the Shapiro-Wilk test with the PROC UNIVARIATE procedure in SAS 9.1 (SAS Institute 2011). The resulting percentage data were submitted to arcsine square root transformation prior to analysis using the SAS function ARSIN (SQRT(x)). After arcsine square root transformation, the data met the assumption of normality required for ANOVA tests. Then, all data were subjected to analyses using the PROC GLM procedure in SAS 9.1. (SAS Institute 2011). Treatment differences were determined using least-square means statements (LSMEANS) at a $P=0.05$ level of significance in SAS 9.1 (SAS Institute 2011). In the bioassay to evaluate the availability of toxic bait and populations, the data were submitted to the $t$ test at $5 \%$ significance. For the evaluation of the effect of each treatment on insect survival, survival curves and respective lethal times $\left(\mathrm{LT}_{50}\right)$ were determined through the Kaplan-Meier analysis, comparing the survival curves by the log-rank test through the program SigmaPlot (v.12.5, Systat Software Inc., California, USA). Kaplan-Meier and log-rank analyzes were also used to compare the mortality of males and females from each treatment in all bioassays. The determination of the consumption of the toxic baits was carried out by weighing the blade in a precision scales Mettler Toledo model MS204S/A01, by subtracting the initial mass (IM) by the final mass (FM). The possible evaporation of the toxic bait was corrected by the evaporation of the toxic bait containing plates that remained in the same conditions of each experiment (negative control), but without being offered to the insects. The toxic bait consumption data were evaluated for normality by the Shapiro-Wilk test and homoscedasticity by Hartley and Bartlett and later submitted to analysis of 
variance (ANOVA) using the $F$ test $(P<0.05)$ (PROC GLM, SAS Institute 2011). Finding statistical significance, the averages were compared by the Tukey test at a $5 \%$ level of significance $(P<0.05)$ (SAS Institute 2011).

\section{Results}

\section{Susceptibility of populations of $\mathbf{C}$. capitata}

Adults of $C$. capitata that were laboratory bred on an artificial diet (laboratory population) presented a higher mortality rate $\left(F_{3,40}=11.27 ; P<0.001\right)$ when exposed to the toxic bait formulation in the evaluations performed up to 96 HAE ( $97 \%$ mortality) when compared to the field population ( $72 \%$ mortality) (Table 1). The adult survival curves of $C$. capitata (males and females) showed that $C$. capitata adults from the laboratory population were more susceptible to toxic bait formulation in time, presenting the lowest values of $L_{50}\left(L_{5} T_{50}(C l\right.$ $95 \%)=11.16(9.84-12.47)$ hours) when compared to insects from the field population $\left(\mathrm{LT}_{50}(\mathrm{Cl} 95 \%)=18.11(14.22-22.00)\right.$ hours) (Table 1, Fig 1). Regarding the consumption of toxic baits, there were no significant differences $(F=3.31 ; t>0.05)$ between the two populations (laboratory and field population) of $C$. capitata for both the laboratory population and the artificial diet $(2.22 \mathrm{mg})$ and field population $(1.75 \mathrm{mg})$ (Table 1).

\section{Effect of availability of artificial diet}

The presence or absence of artificial diet together with the toxic bait Success ${ }^{\mathrm{TM}}$ 0.02CB formulation + water did not affect the survival $\left(F_{2,20}=8.11 ; P<0.001\right)$ of $C$. capitata adults (males and females) up to 96 HAE (100\% mortality) (Table 1 , Fig 2). Due to the overlapping of the confidence intervals, C. capitata adults showed the same susceptibility when the insects were exposed to the treatments containing toxic bait Success ${ }^{\mathrm{TM}}$ 0.02CB + water + artificial diet $\left(\mathrm{LT}_{50}(\mathrm{Cl}\right.$ 95\%) $=$ 31.09 (27.37-34.80) hours) than insects exposed to the treatment containing toxic bait Success ${ }^{\mathrm{TM}} 0.02 \mathrm{CB}+$ water, without the presence of artificial diet $\left(\mathrm{LT}_{50}(\mathrm{Cl} 95 \%)=31.17(27.72-\right.$ 34.61) hours) (Fig 2). However, in the presence of an artificial diet together with toxic bait Success ${ }^{\mathrm{TM}} 0.02 \mathrm{CB}+$ water, adults of $C$. capitata showed a lower $(6.87 \mathrm{mg})$ toxic bait consumption $(t=5.71 ; \mathrm{df}=39 ; P=0.028)$ when compared with insects for which no artificial diet was available (9.33 $\mathrm{mg}$ ) (Table 1).
Table 1 Average number of alive insects ( $\mathrm{N} \pm \mathrm{SE}$ ), percentage of mortality $(\% \mathrm{M})$, lethal time $\mathrm{LT}_{50}$ (hours), and confidence interval (Cl) and toxic bait consumption (mg) of Ceratitis capitata adults on ingestion bioassay when submitted to the Success ${ }^{\mathrm{TM}}$ $0.02 \mathrm{CB}$ toxic bait formulation

\begin{tabular}{|c|c|c|c|c|}
\hline \multirow[t]{2}{*}{ Bioassay } & \multicolumn{2}{|l|}{$96 \mathrm{HAE}$} & \multirow[t]{2}{*}{$\mathrm{LT}_{50}(\mathrm{Cl} 95 \%)$ (hours) $)^{3}$} & \multirow{2}{*}{$\begin{array}{l}\text { Toxic bait consumption } \\
(\mathrm{mg})^{4}\end{array}$} \\
\hline & $\mathrm{N} \pm \mathrm{SE}^{1}$ & $\% \mathrm{M}^{2}$ & & \\
\hline
\end{tabular}

Susceptibility of $C$. capitata population

$\begin{array}{lllll}\text { Laboratory population } & 0.3 \pm 0.30 \mathrm{a} & 97 & 11.16(9.84-12.47) & 2.22 \pm 0.19 \mathrm{a} \\ \text { Wild population } & 2.7 \pm 0.93 \mathrm{~b} & 72 & 18.11(14.22-22.00) & 1.75 \pm 0.37 \mathrm{a}\end{array}$

Availability of artificial diet with toxic bait

Toxic bait + artificial diet

$0.0 \pm 0.00$ a $\quad 100$

$31.09(27.37-34.80)$

$6.87 \pm 0.79 b$

Toxic bait

$0.0 \pm 0.00$ a $\quad 100$

$31.17(27.72-34.61)$

$9.33 \pm 0.66$ a

Exposure time of toxic bait

\begin{tabular}{|c|c|c|c|c|}
\hline $1 \mathrm{~h}$ & $2.1 \pm 0.71 \mathrm{~b}$ & 76 & $23.90(18.98-28.82)$ & $2.28 \pm 0.24 b$ \\
\hline $2 \mathrm{~h}$ & $0.2 \pm 0.13 a$ & 98 & $24.01(20.16-27.86)$ & $2.90 \pm 0.22 b$ \\
\hline $4 \mathrm{~h}$ & $0.0 \pm 0.00 \mathrm{a}$ & 100 & $16.85(14.37-19.32)$ & $4.45 \pm 0.31 \mathrm{a}$ \\
\hline $8 \mathrm{~h}$ & $0.0 \pm 0.00 \mathrm{a}$ & 100 & $14.89(12.46-17.33)$ & $4.65 \pm 0.23 a$ \\
\hline \multicolumn{5}{|c|}{ Influence of $C$. capitata age on toxicity of toxic bait } \\
\hline 1 day old & $6.6 \pm 0.83 c$ & 33 & $15.51(12.95-18.07)$ & $0.93 \pm 0.17 c$ \\
\hline 5 days old & $1.0 \pm 0.45 \mathrm{a}$ & 89 & $35.51(31.14-38.88)$ & $1.57 \pm 0.20 b$ \\
\hline 8 days old & $2.9 \pm 0.81 b$ & 67 & $45.56(36.18-54.94)$ & $2.00 \pm 0.19 a$ \\
\hline \multicolumn{5}{|c|}{ Time of food diet deprivation } \\
\hline h deprivation & $0.0 \pm 0.00 \mathrm{a}$ & 100 & $24.72(21.51-27.94)$ & $2.28 \pm 0.19 b$ \\
\hline $\mathrm{h}$ deprivation & $0.0 \pm 0.00 \mathrm{a}$ & 100 & $15.55(12.96-18.13)$ & $4.64 \pm 0.15 a$ \\
\hline $4 \mathrm{~h}$ deprivation & $0.0 \pm 0.00 \mathrm{a}$ & 100 & $9.24(6.83-13.65)$ & $5.33 \pm 0.29 a$ \\
\hline
\end{tabular}

${ }^{1}$ Values represent means \pm SE. A separate ANOVA (Tukey's test, $P<0.05$ ) was conducted for treatments within each column (means followed by the same letter in column are not significantly different).

${ }^{2}$ Mortality calculated by the formula of Henderson and Tilton (1955).

${ }^{3} \mathrm{LT}_{50}=$ time required to kill $50 \%$ of a tested population.

${ }^{4}$ Estimated value through of subtraction of the initial mass (IM) of the final mass (FM) in each blade. 


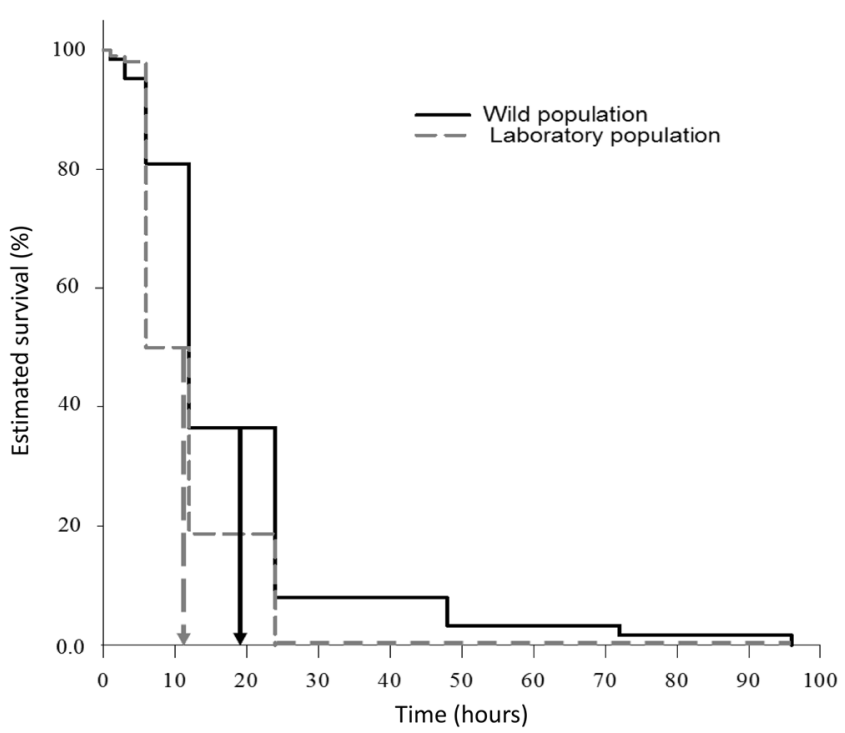

Fig 1 Survival of Ceratitis capitata adults of which larvae were reared in fruits of mango ( $M$. indica) (wild population) and artificial diet (laboratory population) and exposed to the toxic bait Success ${ }^{\mathrm{TM}}$ $0.02 \mathrm{CB}$, containing $96 \mathrm{mg} \mathrm{L}^{-1}$ of spinosad in laboratory. Arrows indicate the lethal time $\left(\mathrm{LT}_{50}\right)$ of the Success ${ }^{\mathrm{TM}} \mathrm{O}$.02CB toxic bait in each parameter evaluated.

\section{Exposure time of toxic bait to adults of $\boldsymbol{C}$. capitata}

Insects that were exposed to toxic bait formulation for 2, 4, or $8 \mathrm{~h}$ presented $100 \%$ mortality and a higher susceptibility $\left(F_{3,38}=21.14 ; P<0.001\right)$ to toxic bait when compared to exposed adults of $C$. capitata for $1 \mathrm{~h}$ ( $76 \%$ mortality) (Table 1$)$. However, due to the overlap of confidence intervals estimated from survival curves, insects exposed for $8 \mathrm{~h}\left(\mathrm{LT}_{50}(\mathrm{Cl}\right.$

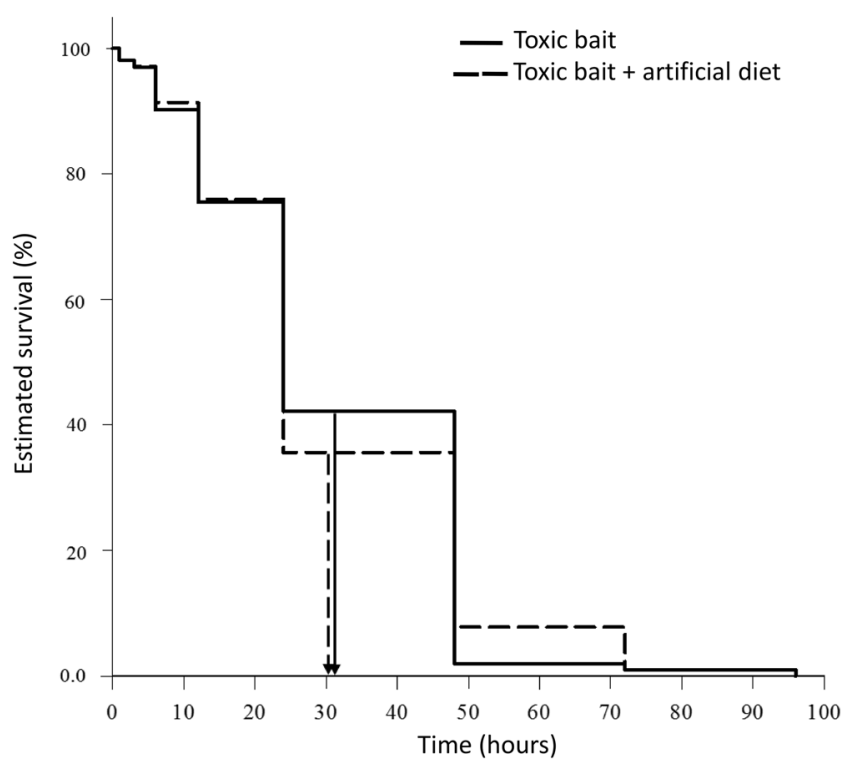

Fig 2 Survival of Ceratitis capitata adults after exposure to the toxic bait Success ${ }^{\mathrm{TM}} 0.02 \mathrm{CB}$, containing $96 \mathrm{mg} \mathrm{L}^{-1}$ of spinosad alone or with artificial diet in laboratory. Arrows indicate the lethal time $\left(\mathrm{LT}_{50}\right)$ of the Success ${ }^{\mathrm{TM}} 0.02 \mathrm{CB}$ toxic bait in each parameter evaluated.
$95 \%)=14.89(12.46-17.33))$ and $4 \mathrm{~h}\left(\mathrm{LT}_{50}(\mathrm{Cl} 95 \%)=16.85\right.$ (14.37-19.32)) to toxic baits presented the lowest values of $\mathrm{LT}_{50}$ (Table 1, Fig 3), differing from adults of $C$. capitata who were exposed to toxic baits for $1 \mathrm{~h}\left(\mathrm{LT}_{50}(\mathrm{Cl} 95 \%)=23.90\right.$ $(18.98-28.82))$ and $2 \mathrm{~h}\left(\mathrm{LT}_{50}(\mathrm{Cl} 95 \%)=24.01(20.16-27.86)\right)$ (Table 1). Therefore, insects exposed to toxic bait feeding for $4 \mathrm{~h}$ (4.45 mg) and $8 \mathrm{~h}$ (4.65 mg) presented a higher consumption $\left(F_{3,38}=20.59 ; P<0.0001\right)$ when compared to insects exposed for $1 \mathrm{~h}(2.28 \mathrm{mg}$ ) and $2 \mathrm{~h}$ (2.90 $\mathrm{mg}$ ) (Table 1$)$.

\section{Influence of age on toxicity of $\boldsymbol{C}$. capitata to toxic bait}

In evaluations of up to $96 \mathrm{HAE}$, it was observed that adults of C. capitata that were 1 day old had the lowest susceptibility $\left(F_{3,39}=14.08 ; P<0.001\right)$ to the formulation of the toxic bait (33\% mortality) (Table 1). However, the highest adult mortality of $C$. capitata occurred with 5-day-old insects (89\% mortality) and was statistically higher $\left(F_{3,39}=14.08 ; P<0.001\right)$ than 8 -day-old insects (67\% mortality) (Table 1$)$. When analyzing survival curves and estimates of lethal times, it was found that 8-day-old adults of $C$. capitata responded similarly $\left(\mathrm{LT}_{5 \mathrm{O}}(\mathrm{Cl}\right.$ 95\% $\left.)=15.51(12.95-18.07)\right)$ to adults of $C$. capitata at 5 days old $\left(\mathrm{LT}_{50}(\mathrm{Cl} 95 \%)=35.51(31.14-38.88)\right)$, but less rapidly compared to 1-day-old insects $\left(\mathrm{LT}_{50}(\mathrm{Cl} 95 \%)=45.56\right.$ (36.18-54.94)) (Table 1; Fig 4). However, 8-day-old insects had a higher consumption of toxic bait $(2.00 \mathrm{mg})$, being significantly higher $\left(F_{2,28}=8.34, P<0.001\right)$ when compared to 5-day-old insects (1.57 mg) and 1-day-old insects (0.93 mg) (Table 1).

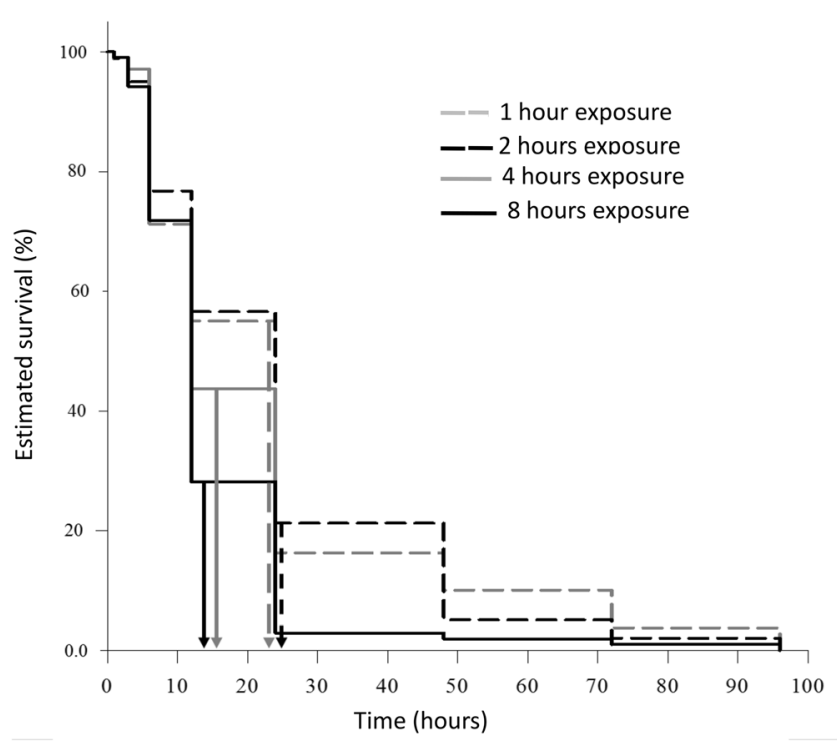

Fig 3 Survival of Ceratitis capitata adults after exposure to the toxic bait Success ${ }^{\mathrm{TM}} 0.02 \mathrm{CB}$, containing $96 \mathrm{mg} \mathrm{L}^{-1}$ of spinosad offered for 1, 2, 4, and $8 \mathrm{~h}$ in laboratory. Arrows indicate the lethal time $\left(\mathrm{LT}_{50}\right)$ of the Success $^{\mathrm{TM}} 0.02 \mathrm{CB}$ toxic bait in each parameter evaluated. 


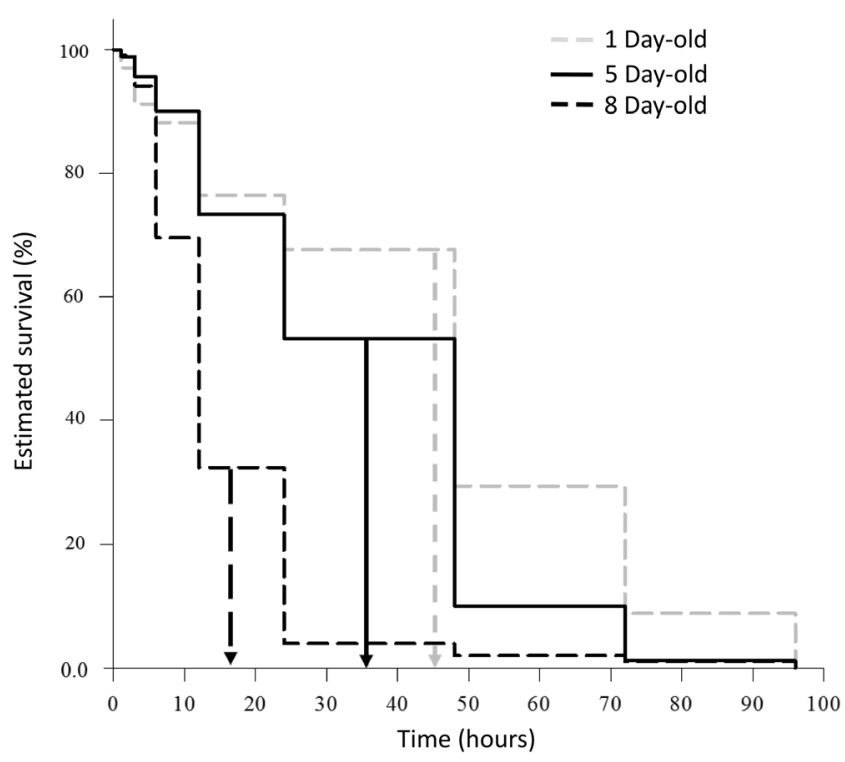

Fig 4 Survival of Ceratitis capitata adults exposed to the toxic bait Success $^{\mathrm{TM}} \mathrm{0.02 \textrm {CB }}$, containing $96 \mathrm{mg} \mathrm{L}^{-1}$ of spinosad in laboratory. Arrows indicate the lethal time $\left(\mathrm{LT}_{50}\right)$ of the Success ${ }^{\mathrm{TM}}$ 0.02CB toxic bait in each parameter evaluated.

\section{Period of food deprivation before exposure C. capitata} to toxic bait

There were no significant differences $\left(F_{2,28}=9.12 ; P>0.05\right)$ in mortalities of $C$. capitata adults in the presence or absence of food deprivation (artificial diet) up to 96 HAE (100\% mortality) (Table 1). However, when analyzing survival curves and $\mathrm{LT}_{50}$ values, it was observed that insects that were deprived of food for $24 \mathrm{~h}$ showed a greater susceptibility to the toxic bait formulation in time $\left(\mathrm{LT}_{50}(\mathrm{Cl} 95 \%)=9.24(6.83-13.65)\right.$ hours) when compared to insects that experienced $12 \mathrm{~h}$ $\left(\mathrm{LT}_{50}(\mathrm{Cl} 95 \%)=15.55(12.96-18.13)\right.$ hours $)$ and $\mathrm{o} h$ of food deprivation $\left(\mathrm{LT}_{50}(\mathrm{Cl} 95 \%)=24.72(21.51-27.94)\right.$ hours $)$ (Table 1; Fig 5). In relation to the consumption of toxic bait, insects that were deprived for $12 \mathrm{~h}(4.64 \mathrm{mg})$ and $24 \mathrm{~h}$ (5.33 $\mathrm{mg}$ ) of the food source (artificial diet) had a higher $\left(F_{2,28}=34.41, P<0.0001\right)$ toxic bait consumption when compared to insects that were not deprived (o-h deprivation) of the food source $(2.28 \mathrm{mg}$ ) (Table 1).

\section{Discussion}

The development of an adequate bioassay methodology with toxic baits is fundamental to obtain satisfactory and reliable results for the design of management strategies. In the present study, when analyzing the parameters of origin of the insect population, period of food deprivation, time, and supply of the toxic bait together with another food source (artificial diet), a difference was found in the behavioral response of the individuals, due to the need to ingest nutritional foods

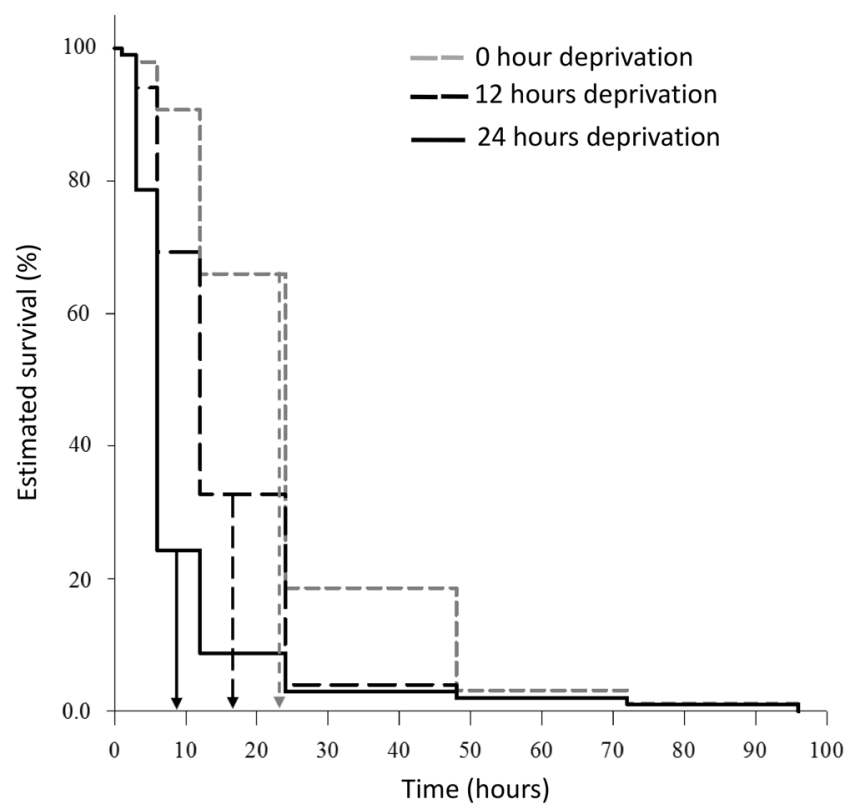

Fig 5 Survival of Ceratitis capitata adults submitted to o-h, 12-h, and 24-h deprivation periods and exposed to the toxic bait Success ${ }^{\mathrm{TM}}$ $0.02 \mathrm{CB}$, containing $96 \mathrm{mg} \mathrm{L}^{-1}$ of spinosad in laboratory. Arrows indicate the lethal time $\left(\mathrm{LT}_{50}\right)$ of the Success ${ }^{\mathrm{TM}} 0.02 \mathrm{CB}$ toxic bait in each parameter evaluated.

for the maintenance of the energy reserves and maturation of the reproductive apparatus of the females (Bateman and Morton 1981, Raga and Sato 2016). In all bioassays performed, adults of $C$. capitata were fed the toxic bait drops $(40 \mu \mathrm{L})$ of the Success ${ }^{\mathrm{TM}} \mathrm{O} .02 \mathrm{CB}$ formulation, containing $96 \mathrm{mg} \mathrm{L}^{-1}$ of spinosad. This aspect is very important for the evaluation of the toxicity of formulations of toxic baits, as one of the main factors influencing the efficiency of the formulations is the phage-stimulating effect of the supplied material, which provides a greater or lesser attractiveness (Nestel et al 2004).

Adults of $C$. capitata from larvae developed on artificial diet showed greater susceptibility to the Success ${ }^{\mathrm{TM}} 0.02 \mathrm{CB}$ toxic bait compared to insects from larvae developed in mango fruits, even though they had the same bait consumption. These factors may be related to the activation or inhibition of detoxifying enzymes induced by allelochemicals present in the food source (Fitt 1986). Thus, the insects that developed during the larval phase in mango fruits may have consumed chemical compounds that are present and that, in turn, provided less susceptibility in relation to those insects that developed in artificial diet. Although there are no records of populations of $C$. capitata adults resistant to spinosynbased insecticides in Brazil, the fact of adults who emerged from field collected in mango orchards in the Casa Nova, BA municipality, larvae may be an indication of changes in the allelic frequency of resistance genes of the population (Couso-Ferrer et al 2011). The fact for this possibility is related to the high population level of $C$. capitata in the region and 
the Success ${ }^{\mathrm{TM}}$ 0.02CB toxic bait is used in a large scale for C. capitata management (Baronio et al 2018).

The survival curves obtained for the treatments (with and without the presence of a food source along with the toxic bait) verified that the addition of a food source to the toxic bait exposure did not provide less susceptibility to the population. However, in the absence of the food source, the adults of $C$. capitata presented a higher intake of the toxic bait drop. For an ingestion experiment aimed at the evaluation of formulations of toxic baits, the longer the insect remains feeding and the greater the amount of food intake consumed, the greater the possibility of intoxication by the lethal agent and, consequently, the faster the effect of the product on the insect (Raga \& Galdino 2018). Thus, the supply of another food source along with the toxic bait can reduce the consumption of the toxic bait and, consequently, the amount of lethal agent ingested by the insect (Nestel et al 2004, Raga \& Galdino 2018). This fact may underestimate the lethal dose and the lethal time of the food attraction evaluated, especially if the insecticide does not present a knock-down effect, such as spinosad. However, previous studies have shown that supply of a food source to insects during the bioassay period is necessary, once adults are exposed to only toxic bait or water insect mortality can be high, leading to erroneous conclusions in relation to the toxicity of the toxic bait formulation (Medina et al 2007).

From $12 \mathrm{~h}$ of food deprivation, regardless of the supply period of the toxic bait, ranging from 1 to $8 \mathrm{~h}$, there is a difference in the individuals' response to lethal time and adult survival. This fact may be associated with the fasting period of insects that induced $C$. capitata adults to ingest the toxic bait soon after the supply, resulting in a faster death. However, toxic baits offered during a longer time frame (more than $2 \mathrm{~h}$ ) resulted in higher food consumption by the insects, and consequently, a greater intoxication. This fact demonstrates that consumption of greater than $2.90 \mathrm{mg}$ of the toxic bait Success ${ }^{\mathrm{TM}} 0.02 \mathrm{CB}$ was sufficient to cause significant mortality of the group composed of 10 adult insects of $C$. capitata.

The higher consumption of toxic bait by insects that were deprived of food for 12 and $24 \mathrm{~h}$ is explained by the compensation reaction caused by the time in which the insects remained without feeding, leading them to increase the consumption of the toxic bait after the fast (Raga \& Sato 2005, Medina et al 2007). Females of Ceratitis cosyra (Walker) (Diptera: Tephritidae), fertilized and unfertilized, and deprived of food for $12 \mathrm{~h}$, were more attracted by odors derived from foods such as chicken feces, beer yeast, guava juice, and cane molasses sugar when compared to flies that previously fed on a sugar and protein diet (Manrakhan \& Lux 2008). However, prolonged periods of deprivation (greater than $12 \mathrm{~h}$ ) increased the mortality of the insects of the control treatment, a fact observed in the present study, probably due to the reduction of the energetic reserves (Vargas et al 2002). Warburg \& Yuval (1997) observed increased intake of sugars and proteins by $C$. capitata after periods of 24 -h food deprivation. Likewise, Yee \& Alston (2016) found that adults of Rhagoletis indifferens Curran (Diptera: Tephritidae) who received spinosad without food supplementation (sugar and yeast extract) showed a greater response to a toxic bait composed of sugar and spinosad, presenting faster mortality compared to those who had access to the diet.

Another factor that leads to a higher intake of toxic bait composed of a mixture of an alimentary attractant and a lethal agent is conditioned by the physiological stage of the adults, which is directly associated with the age of the insects (Kapsi et al 2002). These factors influence the search for food, copula, and oviposition sites in the field required for the reproductive success of the species (Rull \& Prokopy 2000). In the case of $C$. capitata, the highest consumption of toxic bait occurred at the ages of 5 and 8 days after emergence, being associated with a greater need to obtain energy and nutrients for the development of the ovaries during the initial phase or for energy replacement (Silva-Neto et al 2010). In addition, the intake of higher amounts of protein during the adult phase of $C$. capitata prolongs its life cycle by 25 days, allowing an increase in the period in which adults can move to different areas, increasing the amount of damaged fruits (Kouloussis et al 2017).

Based on these results, it was evidenced that the origin of the population of $C$. capitata (wild or from laboratory), the form and the time of offer of the toxic bait Success ${ }^{\mathrm{TM}} 0.02 \mathrm{CB}$, the age, and the period of food deprivation of adults of C. capitata directly influenced the toxicity of the toxic bait formulation. Thus, along with the evaluation of the parameters that may interfere negatively in the execution of the bioassays, the definition of a suitable methodology for the evaluation of toxic baits will aid in refining the data and designing bioassays to study new formulations. With adults of $C$. capitata as the experimental model, it was evidenced that adults 5 days old (after emergence), obtained from laboratory rearing on an artificial diet, deprived of food for $12 \mathrm{~h}$, and exposed to toxic bait for $4 \mathrm{~h}$, are suitable for the definition and installation of laboratory bioassays for the development of results that are reliable and replicable.

Acknowledgments The first author gratefully acknowledges the National Council for Scientific and Technological Development (CNPQ) for a doctoral scholarship supporting research funding.

Author Contributions $C A B$ planned, designed, and executed the experimental work and wrote the manuscript; DB conducted the data analyses and wrote the manuscript, MZN and JP planned and executed the experimental work, and FRMG and MB wrote the manuscript. 
Publisher's Note Springer Nature remains neutral with regard to jurisdictional claims in published maps and institutional affiliations.

\section{References}

Adaime R, Santos RS, Azevedo TS, Vasconcelos AS, Souza MSM, SouzaFilho MF (2017) First record of Ceratitis capitata (Wiedemann) (Diptera: Tephritidae) in the State of Acre, Brazil. EntomoBrasilis 10: 259-260

Agrofit (2018) Sistema de agrotóxicos fitossanitários. Available at: http:// extranet.agricultura. gov.br/agrofit_cons/principal_agrofit_cons. Accessed July 2016

Araújo EL, Juliatti FC, Ferreira ADCL, Fernandes EC, Sousa MM (2013) Eficiência de acetamiprido e etofenproxi no controle de Ceratitis capitata (Diptera: Tephritidae), na cultura da mangueira. ASCA: Agropec Cient Semi-árido 9:99-103

Arita LH (1982) Reproductive and sexual maturity of the Mediterranean fruit fly, Ceratitis capitata (Wiedemann). Proc Hawaii Entomol Soc 24:25-29

Baronio CA, Bernardi D, Paranhos BAJ, Garcia FRM, Botton M (2018) Population suppression of Mediterranean fruit fly Ceratitis capitata (Wiedemann) on table grapes using toxic baits. An Acad Bras Ciênc. No prelo

Barry JD, Miller NW, Piñero JC, Tuttle A, Mau RFL, Vargas RI (2006) Effectiveness of protein baits in melon fly and oriental fruit fly (Diptera: Tephritidae): attraction and feeding. J Econ Entomol 99: 1161-1167

Bateman MA, Morton TC (1981) The importance of ammonia in proteinaceous attractants for fruit flies (Diptera: Tephritidae). Aust J Agric Res 32:883-903

Borges R, Machota-Jr R, Boff MIC, Botton M (2015) Efeito de Iscas Tóxicas sobre Anastrepha fraterculus (Wiedemann) (Diptera: Tephritidae). Bioassay 10:1-8

Botton M, Arioli CJ, Machota-Jr R, Nunes MZ, Rosa JM (2016) Moscas-dasfrutas na fruticultura de clima temperado: situação atual e perspectivas de controle através do emprego de novas formulações de iscas tóxicas e da captura massal. Rev Agropec Catarinense 29:103-107

Couso-Ferrer F, Arouri R, Beroiz B, Perera N, Cervera A, Navarro-Llopis V, Castañera $P$, Hernández-Crespo $P$, Ortego $F$ (2011) Cross-resistance to insecticides in a malathion-resistant strait of Ceratitis capitata (Diptera: Tephritidae). J Econ Entomol 104:1349-1356

Fitt GP (1986) The roles of adult and larval specializations in limiting the occurrence of five species of Dacus (Diptera: Tephritidae) in cultivated fruits. Oecologia 69:101-109

Gazit Y, Gavriel S, Akiva R, Rimar D (2013) Toxicity of baited spinosad formulations to Ceratitis capitata: from the laboratory to the application. Entomol Exp Appl 147:120-125

Härter WR, Botton M, Nava DE, Grutzmacher AD, Gonçalves RS, MachotaJr R, Bernardi D, Zanardi OZ (2015) Toxicities and residual effects of toxic baits containing spinosad or malathion to control the adult Anastrepha fraterculus (Diptera: Tephritidae). Fla Entomol 98:202-208

Henderson CF, Tilton EW (1955) Tests with acaricides against the brow wheat mite. J Econ Entomol 48:157-161

Humeres E, Da-Cruz IBM, Oliveira AK (1999) Age and time exposure-related toxicity of Fenthion to male and female Anastrepha fraterculus (Wied.) (Diptera: Tephritidae). An Soc Entomol Brasil 28:285-291

Kapsi R, Mossinson S, Drezner T, Kamensky B, Yuval B (2002) Effects of larval diet on development rates and reproductive maturation of male and female Mediterranean fruit flies. Physiol Entomol 27:29-38

Kouloussis NA, Damos PT, loannou CS, Tsitsoulas C, Papadopoulos NT, Nestel D, Koveos S (2017) Age related assessment of sugar and protein intake of Ceratitis capitata in ad libitum conditions and modeling its relation to reproduction. Front Physiol 8:1-13

Manrakhan A, Lux AS (2008) Effect of food deprivation on attractiveness of food sources, containing natural and artificial sugar and protein, to three African fruit flies: Ceratitis cosyra, Ceratitis fasciventris, and Ceratitis capitata. Entomol Exp Appl 27:133-143

McQuate GT, Liquido NJ (2017) Host plants of invasive tephritid fruit fly species of economic importance. Int J Plant Biol Res 5:1072

Medina P, Perez I, Budia F, Adan A, Vinuela E (2007) Development of an extended-laboratory method to test novel insecticides in bait formulation. IOBC/WPRS Bull 26:59-66

Morelli R, Paranhos BAJ, Costa MLZ (2012) Eficiência de etofenproxi e acetamiprido no controle de mosca-do-mediterrâneo Ceratitis capitata (Diptera: Tephritidae) em pomar de manga. Bioassay 7:1-4

Navarro-Llopis V, Primo J, Vacas S (2012) Efficacy of attract-and-kill devices for the control of Ceratitis capitata. Pest Manag Sci 69:478-482

Nestel D, Nemny-Lavy E, Zilberg L, Weiss M, Akiva R, Gazit Y (2004) The fruit fly PUB: a phagostimulation unit bioassay system to quantitatively measure ingestion of baits by individual flies. J Appl Entomo 128:576-582

Nunes A, Cosca KZ, Faggioni KM, Costa MLZ, Gonçalves RS, Walder JMM, Garcia MS, Nava DE (2013) Dietas artificiais para a criação de larvas e adultos da mosca-das-frutas sul-americana. Pesq Agropec Bras 48: 1309-1314

Paramasivam M, Selvi C (2017) Laboratory bioassay methods to assess the insecticide toxicity against insect pests-a review. Journal of Entomology and Zoology Studies 5:1441-1445

Prokopy RJ, Miller NW, Piñero JC, Oride L, Chaney N, Revis H, Vargas RI (2004) How effective is GF-120 fruit fly bait spray applied to border area sorghum plants for control of melon flies (Diptera: Tephritidae)? Fla Entomol 87:354-360

Raga A, Sato ME (2005) Effect of spinosad bait against Ceratitis capitata (Wied.) and Anastrepha fraterculus (Wied.) (Diptera: Tephritidae) in laboratory. Neotrop Entomol 34:815-822

Raga A, Sato ME (2011) Toxicity of neonicotinoids to Ceratitis capitata and Anastrepha fraterculus (Diptera: Tephritidae). J Plant Prot Res 51: 413-419

Raga A, Sato ME (2016) Controle Químico de moscas-das-frutas. Agência Paulista de Tecnologia dos Agronegócios, São Paulo, pp 1-14

Raga A, Galdino LT (2018) Mosca das frutas: Atração Fatal. Cultivar 109:20-23

Robertson JL, Russell RM, Preisler HK, Savin NE (2007) Bioassays with arthropods. CRC, Boca Raton, FL

Rull J, Prokopy RJ (2000) Attraction of apple maggot flies, Rhagoletis pomonella (Diptera: Tephritidae) of different physiological states to odour-baited traps in the presence and absence of food. Bull Entomol Res 90:77-88

SAS Institute (2011) SAS System - SAS/STAT. computer program, version 9.2. By SAS Institute, Cary, NC. $84 \mathrm{p}$

Silva-Neto AM, Dias VS, Joachim-Bravo IS (2010) Importância da ingestão de proteína na fase adulta para o sucesso de acasalamento dos machos de Ceratitis capitata Wiedemann (Diptera: Tephritidae). Neotrop Entomol 39:235-240

Stark JD, Vargas RI, Miller N (2004) Toxicity of spinosad in protein bait to three economically important tephritid fruit fly species (Diptera: Tephritidae) and their parasitoids (Hymenoptera: Braconidae). J Econ Entomol 97:911-915

Vargas RI, Millar NW, Prokopy RJ (2002) Attraction and feeding responses of Mediterranean fruit fly and a natural enemy to protein baits laced with two novel toxins, phloxine $B$ and spinosad. Entomol Exp Appl 102:273-282

Warburg MS, Yuval B (1997) Circadian patterns of feeding and reproductive activities of Mediterranean fruit flies (Diptera: Tephritidae) on various hosts in Israel. Ann Entomol Soc Am 90:487-495

Yee LW, Alston DG (2016) Sucrose mixed with Spinosad enhances kill and reduces oviposition of Rhagoletis indifferens (Diptera: Tephritidae) under low food availability. J Entomol Sci 51:101-112

Zwolfer H (1983). Life system and strategies or resource exploitation in tephritids. In: The International Symposium on fruit flies of Economic Importance, 1982, Athens. Proceedings. Rotterdam: CEC, 1983. p. 16 